\title{
Study on Patent Trends for Food Waste Recycling Techno logy
}

\section{Lee, Chang Hoon}

Science for Bioproduction Environment, Faculty of Agriculture, Kyushu University | Department of Bio-Environmental Chemistry, College of Agriculture and Life science, Chungnam National University

Kim, Ha-Na

Science for Bioproduction Environment, Faculty of Agriculture, Kyushu University I National Academy of Agricultural Science, RDA

\section{Kim, Seok-Cheol}

Science for Bioproduction Environment, Faculty of Agriculture, Kyushu University | Department of Bio-Environmental Chemistry, College of Agriculture and Life science, Chungnam National University

\section{Kim, Sung Chul}

Science for Bioproduction Environment, Faculty of Agriculture, Kyushu University I National Academy of Agricultural Science, RDA

他

https://doi.org/10.5109/1800845

出版情報：九州大学大学院農学研究院紀要. 62 (1)，pp. 115-122，2017-02-24. Faculty of Agriculture, Kyushu University バージョン :

権利関係 : 


\title{
Study on Patent Trends for Food Waste Recycling Technology
}

\section{Chang Hoon LEE ${ }^{1, \dagger}$, Ha-Na KIM ${ }^{2, \dagger}$, Seok-Cheol KIM ${ }^{1}$, Sung Chul KIM ${ }^{2}$, Jwakyung SUNG ${ }^{1}$, Yoshiyuki SHINOGI ${ }^{3}$ and Taek-Keun $\mathrm{OH}^{2, *}$}

\author{
Science for Bioproduction Environment, Faculty of Agriculture, Kyushu University, \\ Hakozaki 6-10-1, Higashi-ku, Fukuoka city 812-8581, Japan \\ (Received October 31, 2016 and accepted November 4, 2016
}

\begin{abstract}
Food waste in Korea occupied approximately 26\% of the total municipal waste in the year 2013; therefore, the food waste recycling business has been expanded as an alternative to disposal. This study was conducted to assess the competitiveness of Korean technology, research, and development in leading companies by analyzing food waste treatment and recycling patent trends in Japan, Europe, China, the United States, and Korea. A total of 22,972 valid patents publicized or registered between 1990 (by filing date) and May of 2014 (by research initiation date) were reviewed and categorized by technology. The collection-treatment and composting fields both had a steady rise in core technology. Patents related to saline administration, decomposition control, sterilization, odor elimination, and separation of foreign matter were applied for in the collection-treatment field. A number of patents related to composting processes and material utilization were applied for, whereas very few patents related to composting technology were applied for, implying that research for further technical development is necessary.
\end{abstract}

Key words: Food waste, Resource Recycling, Reduction

\section{INTRODUCTION}

By the legal terms of the Waste Control Act in Korea, 'food waste' describes organic waste, including leftover food, disposal storage of food, and food industry by-products (Kim et al., 2010). The quantity of food waste has gradually increased with population growth and lifestyle improvements, and consisted of approximately $27.4 \%$ of total waste in Korea for 2014 (MOE, 2015). Food waste in Korea contains high moisture content, about 80 to $85 \%$, and spoils easily, causing bad odors. These are many problems related to the storage, transportation, disposal, and treatment of food waste. Contamination of the recycling stream by food waste downgrades the quality of recycled products (Park, 2003). Additionally, decomposed food waste buried in landfills can cause stench and leachate, meaning that appropriate treatment facilities must be built, thus increasing disposal costs (Namkoong, 2002).

Food waste is a worldwide issue that has caused environmental problems, deterioration of residential environments, and additional landfills and incinerators to process the waste. A solution to these problems is necessary for advancing the standard of living in modern societies. Existing food waste management policies include expansion of recycling, improvement in transport, expansion

\footnotetext{
1 Department of Bio-Environmental Chemistry, College of Agriculture and Life science, Chungnam National University, Daejeon 305-764, Korea

2 National Academy of Agricultural Science, RDA, Wanju, Jeollabuk-do, 565-851, Korea

Science for Bioproduction Environment, Faculty of Agriculture, Kyushu University, Hakozaki 6-10-1, Higashi-ku, Fukuoka city 812-8581, Japan

The authors contributed equally to this paper as a co-first author.

* Corresponding author (E-mail: ok5382@cnu.ac.kr) (T.K. OH)
}

of treatment facilities, and development of appropriate processing technologies that place an emphasis on rapid treatment. The continued increase in food waste disposal, however, has caused economic and social problems. In response, the government has implemented policy to emphasize reducing food waste (Kim, 2010). Retrieval of food waste in Korea has been implemented gradually by a series of policies: organic waste sorting in 1998, landfill bans in 2005, implementation of the volume-rate disposal system in 2012, and total prohibition of the seadumping of wastewater in 2013 (Phae et al., 1999). The enforcement of food waste-related policies up to 2012 reduced the amount of food waste $20 \%$ or more and caused an economic effect of approximately 160 billion won (Shin, 2013).

Since the implementation of recycling businesses by local councils beginning in 1996, many partially recoverable recycling facilities have been built. At first, mainly feed production and composting were enforced. Processing methods have gradually expanded to include other methods, such as merging sewage and food waste treatment, mushroom cultivation, anaerobic digestion, earthworm breeding, carbonization, and so on (Ryu et al., 2004). Food waste recycling industries need to improve their industrial competitiveness through implementation of specific management strategies, and recycling industries need to be established as a commercial industry for continuous growth.

The purpose of this study, therefore, was to provide objective and systematic patent information for use in strategic programs for recycling research and development. Patents from five areas-Korea, Japan, Europe, the USA, and China-were confirmed from 1990 (by filing date) to May 2014 (by research initiation date). A total of 22,972 valid patents related to the relevant technologies were analyzed. 


\section{MATERIALS AND METHODS}

\section{Criteria for valid patents}

Only valid patents related to food waste treatment and disposal technologies and issues were included for this study. The limited patents related to treating manure, carcasses, and wastewater was excluded. Patents dealing with mass reduction were included for the analysis. These patents covered technologies for dehydration and other weight loss treatments for organic waste resources, such as by-products of the food waste, agricultural, and fishery industries. Patents dealing with waste collection and other treatments were included for the analysis. These patents covered technologies for salinity management, spoilage control, disinfection, odor treatment, and foreign matter separation during the collection process. Patents dealing with billing and metering technologies of organic waste collection were included for the analysis. Patents dealing with waste disposal were included for the analysis. These patents covered technologies for household disposal. Patents dealing with feed, fertilizer, and compost production technologies were included for the analysis. Patents dealing with energetics technologies for use in the production of fertilizer and compost were included. Patents of other organic waste recycling methods were also included.

\section{RESULTS AND DISCUSSION}

\section{Foreign waste production}

The amount of waste produced in 2012 by the United States was 250,890 tons per day, almost the same as in the previous year (250,380 tons per day). The total amount of waste consisted of $71.3 \%$ classified wastes and $28.7 \%$ other wastes. Others consisted of $49 \%$ food, $46 \%$ grass clippings, $5 \%$ inorganic waste, and so on (EPA,
2012). According to data from the National Bureau of Statistics of China, the daily average amount of food waste in year 2013 was 166,000 tons per day, and the annual average food waste was $60,660,000$ tons, or $37 \%$ of the total waste. The amount of all types of waste in Japan showed a gradual reduction from 2003 to 2013. The daily waste disposal per capita also decreased. The largest portion of waste in Japan was as consumable waste, followed by household and business wastes. According to Gustavsson et al. (2011), the annual amount of food losses during harvest, storage, and transport along with food waste were close to 1.3 billion tons globally in 2013. Fruits and vegetables are the most commonly thrown away food waste items.

\section{Korean waste production}

The annual production of food waste in Korea is shown in Table 1. The total waste in 2013 was 382,081 tons per day, a similar amount as in 2012 (382,009 tons per day). The amount of waste in 2012 consisted of $48.9 \%$ construction waste, $38.3 \%$ business waste, and $12.8 \%$ consumable waste. Construction and business wastes increased slightly since 2008, while consumable waste continuously decreased.

\section{Foreign waste treatment status}

Annual waste management for the USA is shown in Table 2. The amount of waste treated in 2012 was 86,620 tons, a similar amount to the previous year, with 65,290 tons going to recycling $(75 \%)$ and 21,330 tons to composting (25\%). The Chinese food waste treatment capability in 2013 was an average of 8,200 tons per day, and the harmless treatment rate was $5 \%$. However, the expected amount of food waste treatment in 2016 is only an average of 30,000 tons per day, with a harmlessness rate of $16.7 \%$. This means that there is a shortage of food

Table 1. Municipal solid waste generation in Korea, 2008-2013

\begin{tabular}{lrrrrrr} 
& \multicolumn{2}{c}{ Unit: ton/day } \\
$\begin{array}{l}\text { Method } \\
\text { of disposal }\end{array}$ & 2008 & 2009 & 2010 & 2011 & 2012 & 2013 \\
\hline Construction & 176,447 & 183,351 & 178,120 & 186,417 & 186,629 & 183,538 \\
Business & 130,777 & 123,604 & 137,875 & 137,961 & 146,390 & 149,815 \\
Consumable & 52,072 & 50,906 & 49,159 & 48,934 & 48,990 & 48,728 \\
\hline Total & 359,296 & 357,861 & 365,154 & 373,312 & 382,009 & 382,081 \\
\hline
\end{tabular}

Table2. Waste disposal methods in the USA by year

Unit: ton/day

\begin{tabular}{lllllll}
\hline $\begin{array}{l}\text { Method } \\
\text { of disposal }\end{array}$ & 2000 & 2005 & 2008 & 2010 & 2011 & 2012 \\
\hline $\begin{array}{l}\text { Recycling } \\
\text { Composting }\end{array}$ & 53,010 & 59,240 & 61,900 & 64,990 & 66,310 & 65,290 \\
\hline Total & 16,450 & 20,550 & 22,100 & 20,170 & 20,570 & 21,330 \\
\hline
\end{tabular}


Table 3. Waste disposal methods in Japan by year

\begin{tabular}{|c|c|c|c|c|c|c|}
\hline $\begin{array}{l}\text { Method } \\
\text { of disposal }\end{array}$ & 2007 & 2008 & 2009 & 2010 & 2011 & 2012 \\
\hline Recycling & 37,011 & 35,742 & 34,517 & 33,799 & 34,327 & 35,311 \\
\hline Composting & 129 & 136 & 152 & 165 & 184 & 160 \\
\hline Feed & 0 & 4 & 8 & 5 & 8 & 7 \\
\hline Resources & 3,417 & 3,109 & 3,025 & 3,198 & 3,125 & 3,040 \\
\hline
\end{tabular}

Table 4. Waste disposal methods in Korea by year

\begin{tabular}{lrrrrrr}
\hline $\begin{array}{l}\text { Method } \\
\text { of disposal }\end{array}$ & 2008 & 2009 & 2010 & 2011 & 2012 & 2013 \\
\hline Recycling & 82.3 & 81.7 & 83.4 & 83.7 & 84.4 & 84.0 \\
Landfill & 10.5 & 11.1 & 9.4 & 9.1 & 8.8 & 9.3 \\
Incineration & 5.2 & 5.2 & 5.3 & 5.6 & 6.0 & 6.0 \\
Ocean-dumping & 2.0 & 2.0 & 1.9 & 1.6 & 0.8 & 0.7 \\
\hline
\end{tabular}

waste treatment facilities. The Japanese annual waste treatments are shown in Table 3. The incineration and feed resources of Japanese waste treatment remained at a similar amount or slightly decreased, but the composting facility capacity gradually increased. Direct incineration of waste was the largest treatment amount, followed by recycling and composting.

\section{Korean waste treatment status}

Annual waste treatment amounts in Korea are shown in Table 4. The primary waste treatments in Korea were recycling and landfill, while incineration and oceandumping had insignificant levels. Recycling and incineration proportions gradually increased, while a decreasing trend can be seen for landfill and sea-dumping proportions.

\section{Patent trends by country}

The annual patent status of food waste technologies in the major regional markets is shown in Fig. 1. Patent applications related to food waste treatment and recycling technologies appeared in 1973, but activity was weak until the late 1980s. Patenting activity had rapid increases to a peak between 1990 and the early 2000s, followed by a subsequent slight decrease in activity. These trends were heavily influenced by an increase in global awareness of environmental problems in the 1990s, as evidenced in the 1992 UN conference on the environment and development (Rio de Janeiro, Brazil), the London protocol of 1996, and the Kyoto protocol of 1997. The nations of Korea, the USA, and China have had increasing numbers of patents, while the patent activities in Japan trend rapidly downwards after reaching a peak in the early 2000s. The patenting activities in Europe were generally weak. Beginning in 1995, Korean patenting activities rapidly increased due to the volume- rate garbage disposal system that went into effect that year. The patenting activities in China were weak until the early 2000s, but have become more active since the mid-2000s. Related patent applications have increased due to economic growth, increase in income level, and population growth in China over the last 10 years. The interest in food waste recycling in Japan was improved by penalties and subsidies enacted by the 2001 Food Recycling Law, and patent applications reached a peak there in the early 2000s. However, there has been a recent downswing in relevant patenting activities due to an absence of interest in food waste treatment machines to meet the needs of consumers.

\section{Domestic and foreign patent applications in each region}

The numbers of domestic and foreign patent applications in the major regional markets of Korea, the USA, Japan, and Europe are shown in Fig. 2. A national patent application must be filed at a national patent office to obtain a patent in the country of that office. The number of patent applications is an indicator of the patent rights activity in a specific market. The applicant country can be attributed to the country of applicant residence, or to the patent ownership country. The country of applicant residence can be classified as domestic or foreign to identify the predominant native technologies and any reliance on foreign technologies. By tracking annual changes in the numbers of domestic and foreign patent applications, it is also possible to grasp the inflow of foreign technologies to a specific market. Referring to Fig. 3, all nations except the USA and Europe have very few foreign applications, so patent rights have been mainly formed for domestic residents. The applicants with Korean and Japanese nationality are in the top 3 for all regions except Europe, and have a relatively active 

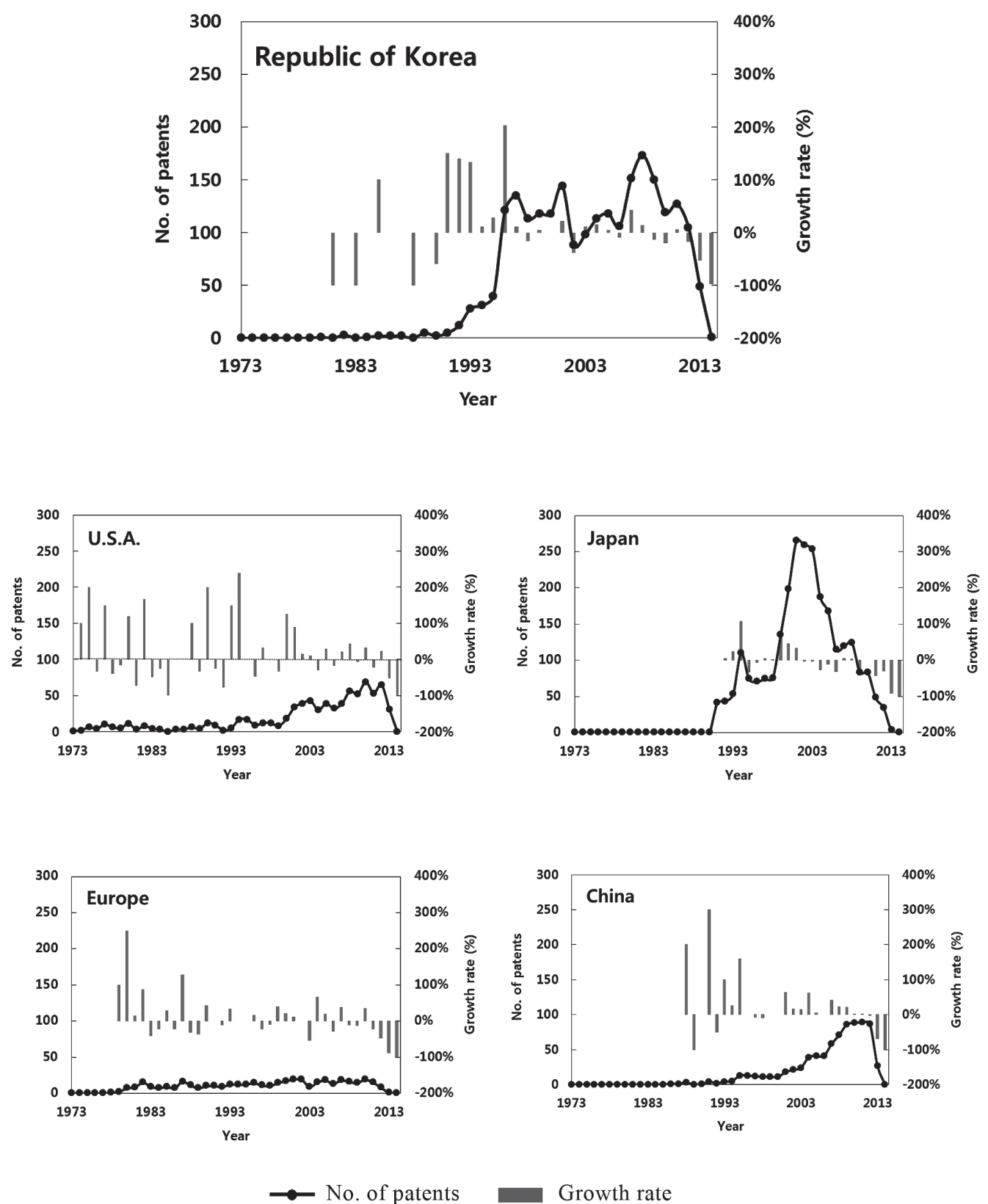

Fig. 1. Trends in patent applications by country.

study. Domestic and foreign patent activity in the USA has been continuously active since the early 2000s, while in Europe applications from aliens have surpassed those by locals during that time. Higher technology independence is evident for Korea, Japan, and China, with dominantly domestic patent activity.

\section{Regional technology market growth}

Development of food waste treatment and recycling technologies through time for the five regions is shown in Fig. 3. Patent application trends are divided into 5 periods, with the total number of patent applicants and applications shown by region for each period. The size of the bubbles indicates the technology strength, while the line indicates trends through time. The study years were divided into 5 periods: Period $1-1988$ to 1992 ,
Period 2 - 1993 to 1997, Period 3 - 1998 to 2002, Period $4-2003$ to 2007, and Period 5 - 2008 to 2012. Korean patent technologies have remained in the growth phase, as indicated by the continuous increase in application numbers from Period 1 to Period 5. This rapid technological development was achieved through a significant increase in the number of applicants and applications from Period 2 to Period 3. American patent technologies are also in the growth phase, with a continuous increase in the numbers of applicants and applications from Period 1 to Period 5, though the total numbers are low. It is assumed that this is due to a lack of technical support for food waste treatment and recycling in the USA. Japanese patent technologies were in the growth phase, with the numbers of applicants and applications increasing from Period 1 to Period 4, but then decreasing in 



Fig. 2. Domestic and foreign patent applications in the major markets.

Period 5. Additionally, a rapid decrease in the numbers of applicants and applications from Periods 3 and 4 to Period 5 is interpreted to have greatly reduced the frequency of technical development. It is assumed that this is due to a large effect from large-scale national support in Japan in the late 1990s. The more recent decline phase appears to be due to a lack of national support. The position of patent technologies in Europe went through a growth phase, with a continuous increase in the numbers of applicants and applications from Period 1 to Period 3, followed by a gradual decline phase to Period 5. Accurate analysis is very difficult due to a lack of patent data in Europe. Patent technologies in China show a continuous increase in the numbers of applicants and applications from Period 1 to Period 5, with a large leap in applications between Period 4 and Period 5.

\section{Core Technology Analysis}

The numbers of patent applications for waste treatment and recycling technologies in the major regional markets for each period are shown in Fig. 4, and the proportions of the technical share of each technology category for each period are shown in Fig. 5. There were more applications for collection-processing technologies than for weight loss technologies, except in Period 1 (1988 to 1992). From the beginning, patent activity in composting technologies has been the most active. Recently, the patent activity in energetics technologies has become more active, while that in feed technology has become relatively weak. The reduced importance in feed technologies is due to the fact that most of the animal feed products come from cheap cones and grains in 

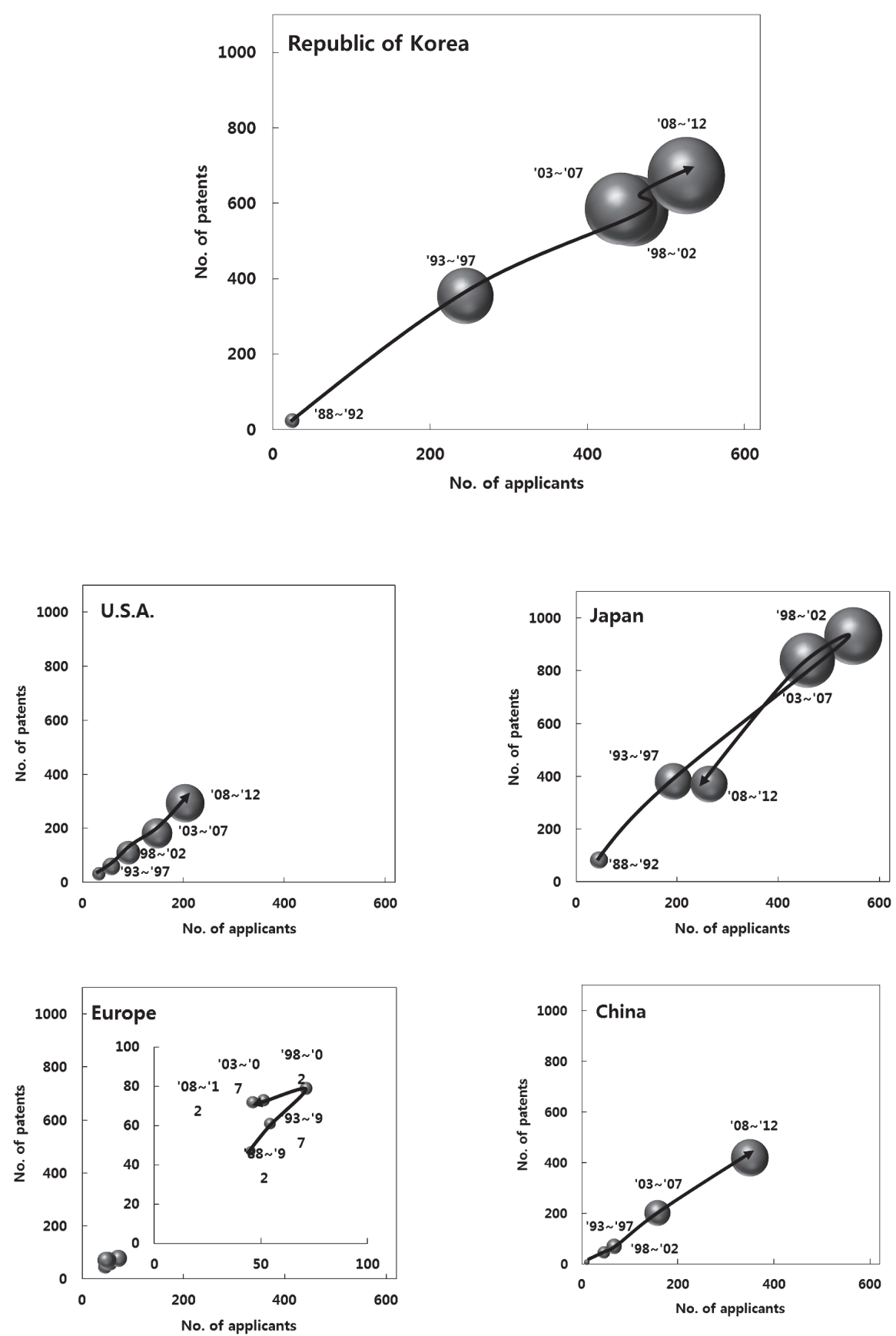

Fig. 3. Patent applicants and applications for five countries, based on the year of application: 1988 1992, 1993 1997, 1998 2000, 2003 2007, 2008 2012.

the USA and Europe. Non-uniform nutrients and infection by pathogenic microorganisms are both problems with using waste material. The share of the treatment field increased in Period 5 (2008 2012), because of an increasing spread in treatment technologies for household food waste. Patent activities in the metering and billing system have primarily occurred in Korea, with very slight activity in the USA, Japan, Europe, and China. It is assumed that pay-as-you-dispose policies in Korea have spurred instantaneous meter-reading technology.

\section{Major Patent Applicants}

Table 5 shows the multi-patent applicants for each country, and the patent technologies that they have con- centrated on. The related major patent applications have been displayed separately for each technology category, so that it is possible to identify the variety of technological fields applicants have concentrated on. Woongjin Coway, Daewoo Electronics, and LG Electronics have been the major patent applicants in Korea. Patent activities were dominated by Emerson Electric and Xyleco Inc. in the USA, and by Panasonic Corp. and Sanyo Electric in Japan. Patent activities were dominated by Emerson Electric and Xyleco Inc. in Europe. Universities that are multi-patent applicants occupy the position just below the international companies. 


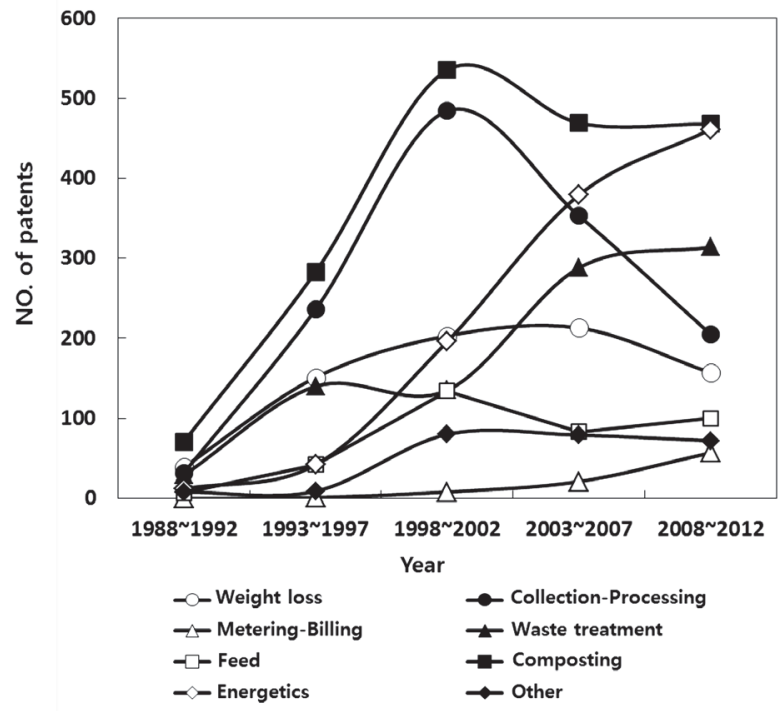

Fig. 4. Number of patent applications for recycling technologies by category in major market countries.

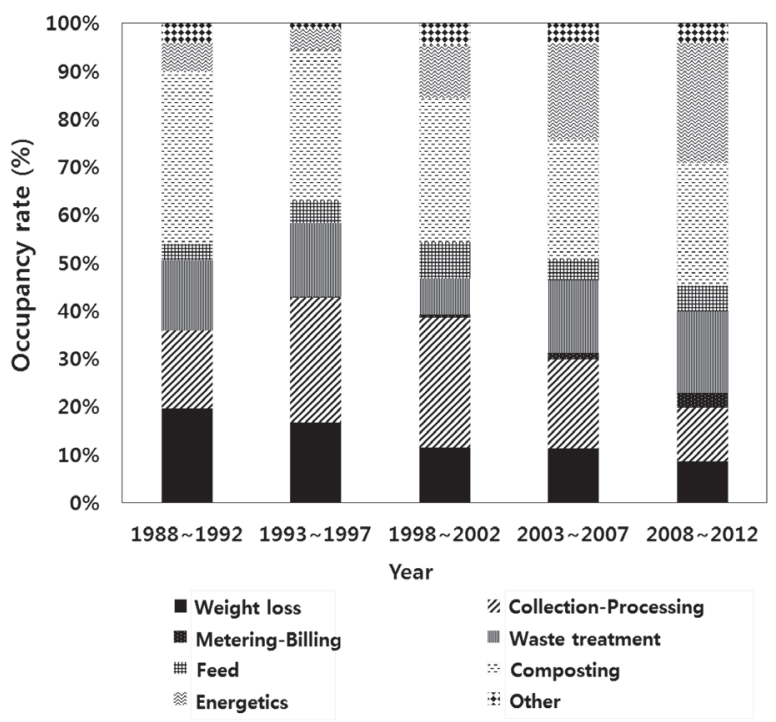

Fig. 5. Percent use of waste treatment technologies by category in major market countries.

Table 5. Main patent application trends in the major markets

\begin{tabular}{|c|c|c|c|c|c|}
\hline Country & Republic of Korea & U.S.A. & Japan & Europe & China \\
\hline \multirow{12}{*}{$\begin{array}{l}\text { Name of } \\
\text { applicant } \\
\text { (Number of } \\
\text { patents) }\end{array}$} & $\begin{array}{c}\text { DAWOO } \\
\text { ELECTRONICS(47) }\end{array}$ & $\begin{array}{c}\text { EMERSON } \\
\text { ELECTRIC(51) }\end{array}$ & $\begin{array}{l}\text { PANASONIC } \\
\text { CORP(313) }\end{array}$ & $\begin{array}{c}\text { EMERSON } \\
\text { ELECTRIC(32) }\end{array}$ & $\begin{array}{c}\text { EMERSON } \\
\text { ELECTRIC(32) }\end{array}$ \\
\hline & LG(37) & XYLECO INC(46) & $\begin{array}{c}\text { SANYO } \\
\text { ELECTRIC(62) }\end{array}$ & XYLECO INC(17) & XYLECO INC(11) \\
\hline & $\begin{array}{l}\text { WOONGJIN } \\
\text { COWAY(27) }\end{array}$ & $\begin{array}{l}\text { WOONGJIN } \\
\text { COWAY(6) }\end{array}$ & $\begin{array}{l}\text { PANASONIC } \\
\text { ELECTRIC } \\
\text { WORKS(50) }\end{array}$ & EBARA CORP(6) & $\begin{array}{l}\text { Tianjin Normal } \\
\text { University(10) }\end{array}$ \\
\hline & $\begin{array}{c}\text { LONNAI } \\
\text { KOREA(23) }\end{array}$ & $\begin{array}{c}\text { COUNCIL OF } \\
\text { SCIENTIFIC(6) }\end{array}$ & $\begin{array}{c}\text { MITSUBISHI HEAVY } \\
\text { IND(37) }\end{array}$ & $\begin{array}{l}\text { WOONGJIN } \\
\text { COWAY(5) }\end{array}$ & Hunan Univ.(10) \\
\hline & SEO HEE DONG(18) & $\begin{array}{l}\text { WOONGJIN } \\
\text { COWAY(5) }\end{array}$ & EBARA CORP(31) & Medoff Marshall(5) & $\begin{array}{c}\text { Zhejiang } \\
\text { University(7) }\end{array}$ \\
\hline & $\begin{array}{l}\text { YANG KYUNG } \\
\text { SUN(14) }\end{array}$ & Medoff Marshall(5) & $\begin{array}{l}\text { KURITA WATER IND } \\
\text { LTD(23) }\end{array}$ & TILS, PETER(3) & $\begin{array}{l}\text { North China Electric } \\
\text { Power University(6) }\end{array}$ \\
\hline & $\begin{array}{c}\text { KOREA INSTITUTE } \\
\text { OF ENERGY } \\
\text { RESEARCH(10) }\end{array}$ & $\begin{array}{l}\text { BP CORP NORTH } \\
\text { AMERICA INC(4) }\end{array}$ & HITACHI LTD(21) & $\begin{array}{l}\text { SORAIN CECCHINI } \\
\text { S.P.A.(3) }\end{array}$ & $\begin{array}{l}\text { China Agricultural } \\
\text { University(5) }\end{array}$ \\
\hline & $\begin{array}{l}\text { HANBAT NATIONAL } \\
\text { UNIVERSITY(7) }\end{array}$ & VITAG CORP(4) & TOSHIBA CORP(20) & $\begin{array}{c}\text { SANYO } \\
\text { ELECTRIC(3) }\end{array}$ & $\begin{array}{l}\text { WOONGJIN } \\
\text { COWAY(4) }\end{array}$ \\
\hline & GAIA(7) & $\begin{array}{l}\text { NUTRACYCLE } \\
\text { LLC(4) }\end{array}$ & KUBOTA CORP(18) & Nockemann, Otto(3) & $\begin{array}{l}\text { Sun Yat-Sen } \\
\text { University(4) }\end{array}$ \\
\hline & KKS LAND(6) & $\begin{array}{l}\text { MAJESTY THE } \\
\text { QUEEN(4) }\end{array}$ & UEDA TORU(15) & & $\begin{array}{c}\text { Shenyang Aerospace } \\
\text { University(4) }\end{array}$ \\
\hline & KIST(6) & AB CWT LLC(4) & & & \\
\hline & & $\begin{array}{c}\text { 3,INSTITUTE OF } \\
\text { GAS } \\
\text { TECHNOLOGY(4) }\end{array}$ & & & \\
\hline
\end{tabular}




\section{CONCLUSIONS}

In this study, 22,972 valid patent applications in Korea, the USA, Japan, Europe, and China were analyzed. Patent applications for food waste disposal technologies began in 1973, but remained low until the late 1980s. Additionally, patenting activity rapidly increased to a peak between 1990 and the early 2000s, and then decreased again. Even so, patent application activity has still been significant. These trends are a result of a worldwide increase in the awareness of environmental issues in the 1990s, such as from the 1992 UN conference on environment and development (Rio de Janeiro, Brazil), the London protocol of 1996, and the Kyoto protocol of 1997. Regarding the status of domestic and foreign patent applications in the major regional markets, patent activities by the residents were the most active in Korea and Japan, but foreign activities were slight in all countries. Domestic and foreign patent applications in the USA have been continuously active from the early 2000s. Since the 2000s, there have been more foreign than domestic applications in Europe. The growth of technology markets can be represented by the regional number of patent applicants and applications. Rapid technical development in the study period was achieved through a significant increase in the numbers of patent applicants and applications from 1993 to 2002. An increased rate of the technical share (as represented by the number of applicants and applications) in the major regional markets occurred in the composting and collection-processing technologies. The share of the feed technology category recently increased due to an increase in the technology development. Additionally, the share of the treatment category has increased since 2008, due to an increased spread of household food waste treatment technologies. Patent activity in the metering and billing category is greatest in Korea, with low numbers of patents for this category in the USA, Japan, Europe, and China. The dominant patent applicants in the major regional markets are the Korean Daewoo Electronics, Japanese Panasonic Corp., and Emerson Electric in the USA, Europe, and China.

The number of patent applications for food waste treatment and recycling technologies is heavily influenced by related policies. Interest in organic composting and energetics technologies for sewage treatment increased significantly from the announcement of the London Protocol, and will continue to increase with the enforcement schedule of the Sewage Act. Therefore, an active investment to the National Research Department and Universities is necessary for the related technical development, which is expensive. Policies are also needed to spread study results to small and mediumsized businesses.

\section{ACKNOWLEDGMENT}

This work was carried out with the support of the "Cooperative Research Program for Agriculture Science \& Technology Development (Project No. PJ01092502)," Rural Development Administration, Republic of Korea.

This study was based on "A patent analysis for food waste treatment and recycling technology of RDA and Statistics Korea(2014.07)"

\section{REFERENCES}

EPA 2012 Municipal Solid Waste Generation, Recycling, And Disposal in the United States: Facts and Figures for 2012; U.S. Environmental Protection Agency. [Online] Available: https:// www.epa.gov/sites/production/files/2015-09/documents/2012_ msw_fs.pdf [2016 Oct 21]

Gustavsson J., C. Cederberg, U. Sonesson, R. van Otterdijk and A. Meybeck 2011 Global Food Losses and Food Waste: Extent, causes and Prevention. FAO, Rome, Italy.

Kim D. H., J. B. Moon, W. J. Yoo and D. M. Lee 2010 Measuring Efficiency of Recycling Food Wastes Facilities using DEA. J. Korea society for quality manage. 38(2): 212-224

Kim S. H. 2010 Policy Support Status and future direction of reducing food waste, $J$. KORRA 18: 13-19 (in Korean)

MOE (Ministry of Environment) $2015 \quad$ National Waste Generation and Disposal, Korea(2013). [Online] Available: http://webbook.me.go.kr/DLi-File/091/023/006/5607883.pdf [2016 Oct 21] (in Korean)

Phae C. G., H. S. Shim, J. W. Hwang and K. W. Baek. 1999 Change of Microorganism and Effect of temperature control on Garbage composting. KORRA, Autumn Conference (1999. 11) 64-72. [Online] Available: https://www.dbpia.co.kr/ Journal/ArticleDetail/NODE00803317 [2016 Oct 21] (in Korean)

Park S. H. 2013 Effects of Chaff on Aerobic Composting of Food Wastes. Korean J. Environ. Health Sci. 29(2): 56-61 (in Korean)

Ryu J. Y., K. S. Kong, D. Y. Shin and C. G. Phae 2004 Analysis and Improvement Measures on the Status of the Installation and Operation of Facilities for Recycling Food Waste into Compost. J. KORRA, 12(3): 95-111. [Online] Available: http:// www.dbpia.co.kr/Journal/ArticleDetail/NODE00801878 [2016 Oct 21] (in Korean)

Shin J. S. 2013 Administrative plan and management for organic wastes, J. KORRA, Symposium and presentation, Spring Conference(2013. 5), 82-107. [Online] Available: https://www.dbpia.co.kr/Journal/ArticleDetail/NODE02362009 [2016 Oct 21] (in Korean)

Yoo S. S., Y. D. Kim, J. Y. Lee, Y. S. Cha, E. S. Kim, J. S. Jeon, Y. Sunwoo, S. W. Eom and Y. J. Chae 2012 The Characteristic and Management of Odor Emitted from Food waste Treatment Facility. J. Environ Impact Assessment, 21(3): 353-365 